\title{
Simulium (Chirostilbia) brunnescens (Diptera: Simuliidae) - new species from the Brazilian cerrado, Manso Dam, state of Mato Grosso, Brazil
}

\author{
Marilza Maia-Herzog ${ }^{1}$, Ana Carolina dos Santos Valente ${ }^{1 /+}$, Antonio Paulino A Luna-Dias ${ }^{1}$, \\ Leonardo Henrique Gil-Azevedo², Verônica Marchon-Silva'
}

\author{
'Laboratório de Simulídeos e Oncocercose, Instituto Oswaldo Cruz-Fiocruz, Av. Brasil 4365, 21040-900 Rio de Janeiro, RJ, Brasil \\ ${ }^{2}$ Departamento de Zoologia, Instituto de Biologia, Universidade do Estado do Rio de Janeiro, Rio de Janeiro, RJ, Brasil
}

\begin{abstract}
A new species of Simuliidae, Simulium (Chirostilbia) brunnescens, was discovered at Chapada dos Guimarães, state of Mato Grosso, Brazil, and nearby municipalities (Paranatinga, Rosário do Oeste and Nobres). This species is described here based on the adults, pupae and larvae. This species is closely related to Simulium (C.) subpallidum Lutz, but could be differentiated in all stages: females, leg colour pattern and frontal dilatation size; males, gonostyle shape; pupae, number of gill filaments; larvae, body size and colour, postgenal cleft, ratio between antenna and stalk of labral fan.
\end{abstract}

Key words: Insecta - Culicomorpha - taxonomy - Neotropical region - impacted area

According to Adler and Crosskey (2011), three genera of Simuliidae occur in Brazil: Araucnephia Wygodzinsky \& Coscarón, Lutzsimulium d'Andretta \& d'Andretta (2 subgenera) and Simulium Latreille (8 subgenera). The subgenus Simulium (Chirostilbia) is represented by 13 species, all of which are found in Brazil, including one economically important species, the pest Simulium pertinax Kollar. Six species in this subgenus are known from for the state of Mato Grosso (MT), Brazil (Simulium dekeyseri Shelley \& Py-Daniel, Simulium friedlanderi Py-Daniel, S. pertinax, Simulium serranum Coscarón, Simulium spinibranchium Lutz and Simulium subpallidum Lutz). In this paper we describe one additional species: Simulium (Chirostilbia) brunnescens sp. nov., based on adults, pupae and larvae.

\section{MATERIALS AND METHODS}

During field studies of the Simuliidae fauna of the Manso Dam area (MT), carried out by the Laboratório de Simulídeos e Oncocercose, Instituto Oswaldo CruzFundação Oswaldo Cruz (LSO/IOC-Fiocruz), state of Rio de Janeiro, Brazil a new species was found, which is described here. The reservoir has an area of $427 \mathrm{~km}^{2}$ and spans through the municipalities of Chapada dos Guimarães and Nova Brasilândia, in the Brazilian cerrado, a biodiversity hotspot according to Myers et al. (2000). The climate is tropical (hot and humid, with 4-5 dry months). Annual temperatures average $24^{\circ} \mathrm{C}$ and annual rainfall is between $1.250-1.500 \mathrm{~mm}$. The area has a plain relief, with steep cliffs and vegetation

Financial support: LSO/IOC-FIOCRUZ, Eletrobrás Furnas Centrais Elétricas, ANEEL, CNPq

+ Corresponding author: avalente@ioc.fiocruz.br

Received 12 August 2011

Accepted 2 February 2012 typical of the savannas (Brazilian cerrado or tropical savanna), with open arboreal semblance. The mean altitude is $810 \mathrm{~m}$ (Ross 2003).

During this study, a total of 107 collection sites at the municipalities of Chapada dos Guimarães, Paranatinga, Rosário do Oeste and Nobres were investigated. The width and depth range of the sampled sites was $30-20 \mathrm{~m}$ and $10 \mathrm{~cm}-1 \mathrm{~m}$, respectively, however, most of these sites consisted primarily of low order streams. The region has altitudes ranging from 200-633 m, but mainly from 200-252 m. Sampling of immatures was carried out in 2002 (October) and 2003 (February, April and July). Subsequent collections were made in 2010 (January, April, September and November). The following parameters were measured at each site investigated: water temperature, $\mathrm{pH}$ and stream width and depth. On each site, we collected randomly for $15 \mathrm{~min}$ by searching immature in all available substrates. Immatures were manually collected, including the substrate whenever possible and placed into tagged clear plastic bags $(40 \mathrm{~cm} \times 40 \mathrm{~cm})$ that were put into a cooler with ice and transported to the laboratory. Larvae were fixed in $70 \%$ ethanol. Each pupa was placed in an individually tagged microcentrifuge tubes $(1.5 \mathrm{~mL})$ with filter paper to remove excessive humidity and also maintain the humidity in order to allow emergence. Adults were either fixed in $70 \%$ ethanol or pinned. Slides were prepared according to Calvão-Brito and Maia-Herzog (2003). Pictures were taken using a digital camera (Nikon 995, HP Photosmart M307 and Sony Cybershot H5) connected to a Nikon Eclipse E200, or to a Nikon SMZ800 stereomicroscope or using an Imaging Analyses System (Shelley et al. 2000).

The holotype and paratypes are deposited in the Simulids Collections of IOC (CSIOC). Taxonomic comparison with $S$. subpallidum was based on specimens deposited at the CSIOC at the Lutz Collection and at the Simulids Collections of Department of Entomology, Natural History Museum, London, UK (BMNH). 


\section{S. (C.) brunnescens sp. nov.}

M Maia-Herzog, ACS Valente, APA Luna-Dias, LH Gil-Azevedo \& V Marchon-Silva

(Figs 1-32, 36, 38)

Diagnosis - General colour of adults orange brown. Hypoginial valve unsclerotized, subtriangular. Anal lobe triangular. Cerci membranous, hemispherical. Genital fork and vertical anterior process weakly sclerotized, lateral arms well developed and sclerotized. Spermatheca oval, without ornamentation. Claws without subbasal tooth. Ventral plate trapezoid-shaped with short lateral arms and short hairs apicomedially. Gonocoxite subquadrangular with conic gonostylus. Pupae with slippershaped cocoon, light brown. Gills with six filaments in vertical plane, rising from three short primary branches which bifurcate near base, with rounded end. Larvae with body colour generally dirty white with vivid green markings; dorsal view of the head with $1+1$ faint posterolateral spots, posteromedial and anteromedial spots continuous in a distinct longitudinal stripe. Antennae with proximal and medial articles unpigmented contrasting with dark distal article; postgenal cleft deep, longer than wide and rounded; abdomen without ventral tubercles.

Female - Medium size of the species (dried specimens, measurement 2 years after collection). Body length: $1.77-2.02 \mathrm{~mm}$ [mean $=1.89 \mathrm{~mm}$, standard deviation $(\mathrm{SD})=0.086, \mathrm{n}=9$ ] and wing length $\mathrm{x}$ width: $1.96-2.08 \mathrm{~mm}$ (mean $=2 \mathrm{~mm}, \mathrm{SD}=0.039 \mathrm{~mm}, \mathrm{n}=9$ ) x 0.89-1.06 mm (mean $=0.97 \mathrm{~mm}, \mathrm{SD}=0.055, \mathrm{n}=9)$. General colour body in freshly emerged specimens orange brown. Head: eyes green, but dark reddish brown in dried specimens. Frons and clypeus brown with dense silver pruinosity, antenna light brown, mouthparts light brown, maxilla with base of palps dark brown. Frontal dilatation slightly wider at base than at apex, nudiocular area poorly developed (Fig. 38). Palps with segment V equal in length to combined segments III and IV and Lutz sensorial organ well developed, elongated, occupying half of the length of its segment. Lacinia with 18-21 teeth. Mandibles with a row of minute teeth, external
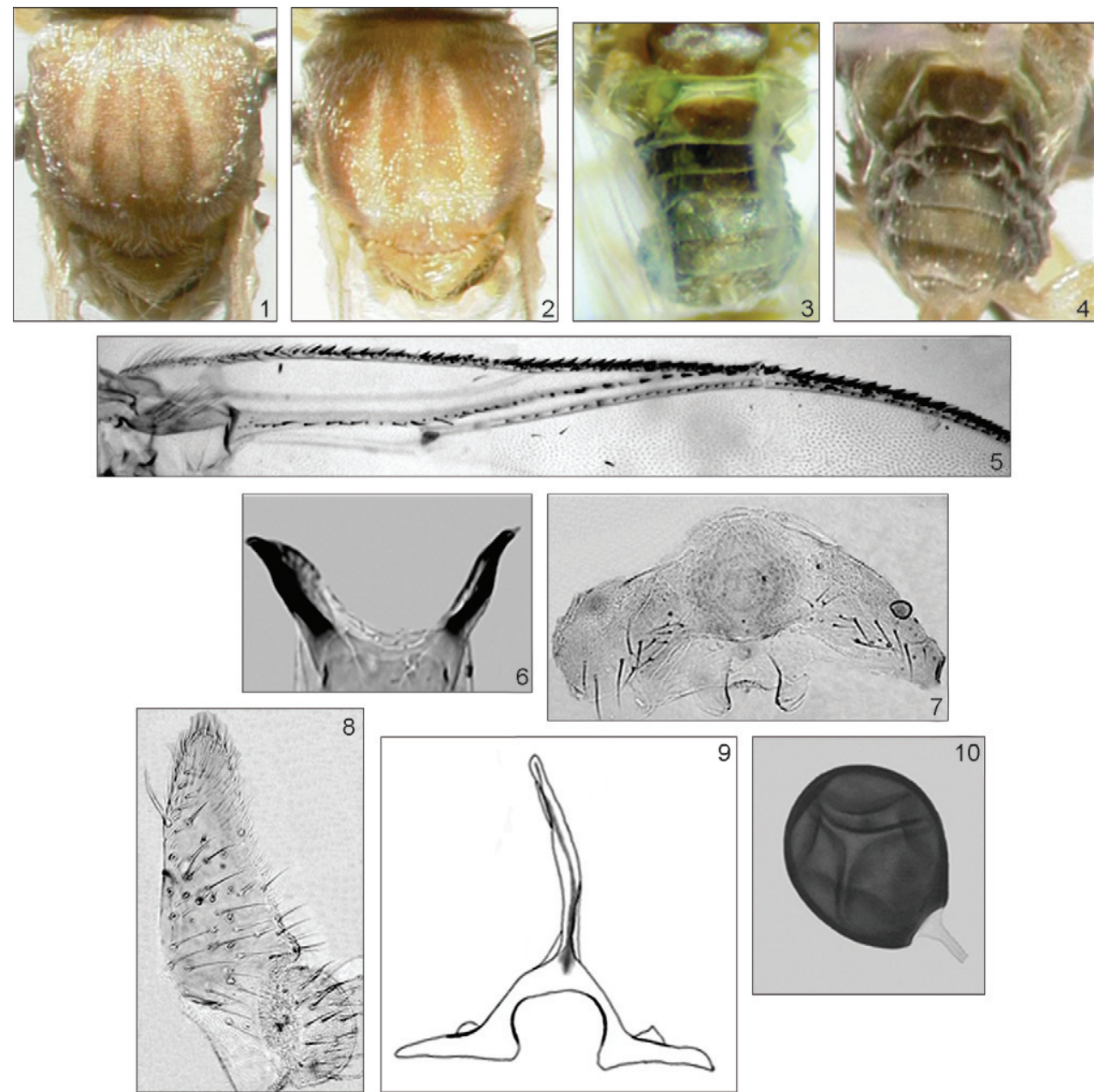

Figs 1-10: Simulium brunnescens sp. nov. (Diptera: Simuliidae) female; 1: scutum colour pattern, anterior illumination; 2: posterior illumination; 3: colour pattern of abdomen, green variation; 4: colour pattern of abdomen, brown variation; 5: part of wing; 6: cibarium; 7: hypogynial valve; 8: anal lobe; 9: schematic drawing of genital fork; 10: spermatheca. 
teeth curved, without space among them. Cibarium unarmed, with sclerotized laterals (Fig. 6). Thorax: scutum orange brown, with golden pilosity, with dark. Some specimens present $1+1$ dark brown shapes at the bottom of scutum external borders. Humeri and pleural membrane greenish yellow. Katepisternum light brown with pruinosity. Scutellum pale yellow; postnotum dark brown. In both standard illumination positions (anterior and posterior), a lyre-shape pattern can be seen, varying in thickness depending on the position of the light source: brown with anterior illumination (Fig. 1) and yellowish brown with posterior illumination (Fig. 2). Wings: costa with a row of spines between setae, subcosta with four-six small setae, basal section of radius with 12-16 setae, the remaining with approximately 12 spines between setae (Fig. 5). Legs: fore leg (Fig. 30): coxa, trochanter and femur yellow; tibia yellow except for distal part brown. Basitarsus and tarsi dark brown. Claws without subbasal tooth. Mid legs (Fig. 31): coxa yellow, with external face brown; trochanter, femur and tibia yellow; basitarsus and tarsi pale yellow with brown distal part; 3rd and 4th tarsi light brown. Claws without subbasal tooth. Hind legs (Fig. 32): coxa, trochanter and three fourths of femur yellow, the rest dark brown. Proximal three fourths of tibia yellow, gradually fading to dark brown. Four fifths of basitarsus light yellow, brown on distal part; half of 2nd tarsi yellow, the rest of tarsi brown. Calcipala and pedisulcus well devel- oped, calcipala wider than long. Claws with small sub basal tooth. Abdomen: general colour brown, but using the same light source positioning, some colour variation can be seen: some specimens present greenish abdomen (Figs 3, 4). Tergites I-II brown, in some specimens bright green, tergites II-V with median velvet brown plates; tergite $\mathrm{V}$ median plate more developed, double the width of the other plates. Tergites IV-VII faint brown, greenish in some specimens. Terminalia: hypoginial valve unsclerotized, subtriangular, with around $6+6$ setae on 8th sternite (Fig. 7). Anal lobe triangular three times as wide as long. Cerci membranous, hemispherical (Fig. 8). Genital fork and vertical anterior process weakly sclerotized, lateral arms well developed and sclerotized (Fig. 9). Spermatheca oval, strongly sclerotized, without ornamentation and microtrichia uniformly arranged throughout the spermatheca, duct junction slightly funnelled, not sclerotized (Fig. 10).

Male - Medium size of the species (dried specimens, measurement 2 years after collection). Body length: $1.70-1.96 \mathrm{~mm}($ mean $=1.83 \mathrm{~mm}, \mathrm{SD}=0.098, \mathrm{n}=10)$, wing length $1.60-1.96 \mathrm{~mm}$ (mean $=1.83$, SD $0.100, \mathrm{n}$ $=10$ ), wing width $0.89-1.19$ (mean $=0.98, \mathrm{SD}=0.085, \mathrm{n}$ $=10$ ). General colour body in freshly emerged specimens orange brown. Head: brown with holoptic eyes, clypeus with gray pruinosity, antenna light brown, maxillary palps dark brown, usually forming a dark-light-dark
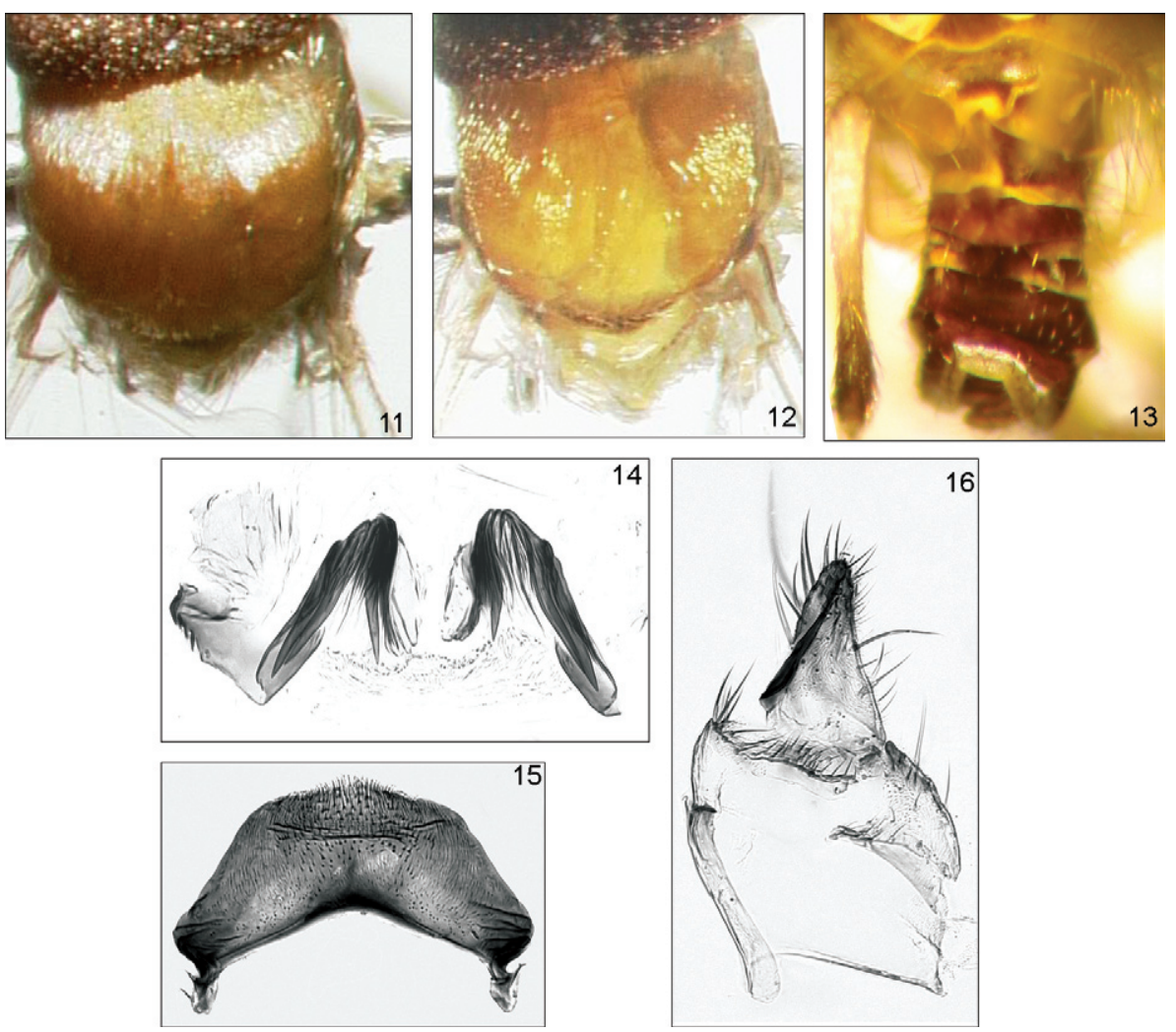

Figs 11-16: Simulium brunnescens sp. nov. (Diptera: Simuliidae) male; 11: scutum colour pattern, anterior illumination; 12: posterior illumination; 13: colour pattern of abdomen; 14: paramere; 15: ventral plate; 16: gonocoxite and gonostyle. 
pattern after the Lutz sensorial organ's segment. Thorax: scutum orange brown, in some specimens present $1+1$ square dark shapes at outer border of the scutum base. Scutum with the anterior illumination brown, anterior portion of scutum with silver pruinosity and golden setae (Fig. 11) and with posterior illumination orange brown with golden setae, scutellum yellow (Fig. 12). Pleural membrane silver, postnotum dark brown, scutellum light brown. Pleural region grayish dark yellow. Terminalia: abdomen yellow with dark brown median plates: tergites I-II light yellow, III-V presenting developed median plate (Fig. 13). Hypopygyum brown. Ventral plate: trapezoid-shaped with short lateral arms and short hairs apicomedially (Fig. 15). Gonocoxite subquadrangular, wider than long, conic gonostylus (Fig. 16). Paramere with $5+5$ apical spines $(3+3$ centrally and $2+2$ laterally) (Fig. 14).

Pupa - Cocoon: length dorsally $2.01-2.81 \mathrm{~mm}$ (mean $=2.50 \mathrm{~mm}, \mathrm{SD}=0.189, \mathrm{n}=18)$, ventrally $2.28-3.63 \mathrm{~mm}$ (mean $=2.81 \mathrm{~mm}, \mathrm{SD} 0.305, \mathrm{n}=18$ ), pupa length: 2.13$3.08 \mathrm{~mm}$ (mean $=2.61 \mathrm{~mm}, \mathrm{SD} 0.245, \mathrm{n}=18)$; gill length: $1.64-2.55 \mathrm{~mm}$ (mean $=1.97 \mathrm{~mm}, \mathrm{SD}=0.225, \mathrm{n}=18)$. Cocoon slipper-shaped, light brown, rim of aperture slightly oblique. Cocoon surface composed of fine, compact and visible fibres. Gills: six filaments in vertical plane, rising from three short primary branches which bifurcate near base. Dorsal primary branch shorter than mid and ventral branches. Gills of pleated appearance, with rounded end (Figs 22, 36). Cephalic plate: $2+2$ frontal trichomes and $1+1$ facial trichomes (Figs 17, 18). Branching of facial trichomes from two-five and of frontal trichomes from onethree. Posterior frontal trichomes with one-two branches. Anterior frontal trichomes with two-three and one-three branches (Fig. 18, positions 3, 5, respectively). Cephalic plate with some tubercules clustered near the base. Thorax: usually with trichomes and spines distributed as in Fig. 20. Anterior margin with two simple spine (Fig. 21, positions 7,8 ) and three trichomes with one-three branches (Fig. 21, positions 6, 9, 10). Dorsally with five trichomes; three near ecdysial line two farther away. The anterior pair of trichome branches (positions 3, 4) ranges from four-seven. The other pair of trichomes (positions 2, 5) has three-six branches. The un-paired trichome has branches number ranging from two-five. Thorax surface sparsely covered with small tubercles, especially at the anterior region. Abdomen: tergites II and III with $4+4$ simple hooks. Sternites V-VII with $2+2$ lateral/ventral hooks and VIII with a row of small triangular hooks (Fig. 19).

Mature larvae - Body colour generally dirty white with green markings (Fig. 23). Body length 3.4-4 mm $(\mathrm{n}=5)$; head capsule dorsal length $0.4-0.6 \mathrm{~mm}$ and dorsal width 0.3-0.4 mm $(\mathrm{n}=5)$; gill histoblast length, in situ $0.4 \mathrm{~mm}$ and width $0.2 \mathrm{~mm}(\mathrm{n}=5)$, dissected with six filaments. Head: dorsal view with dark spots, $1+1$ faint posterolateral spots, posteromedial and anteromedial spots continuous in a distinct longitudinal stripe (Fig. 24). Antennae with proximal and medial articles unpigmented, contrasting with dark distal article; proximal article twice as long as medial article and longer than distal article; medial article shorter than distal one. Antennae slightly longer than labral fan stalk; labral fan with 26-34 rays. Mandibular teeth: one apical, two external, three subapi$\mathrm{cal}$; about 10 internal teeth and two mandibular serration. Hypostomal teeth reduced and next to the hypostomal plate, which partially covers the teeth (Fig. 29); hypostoma with concave border and with median tooth height
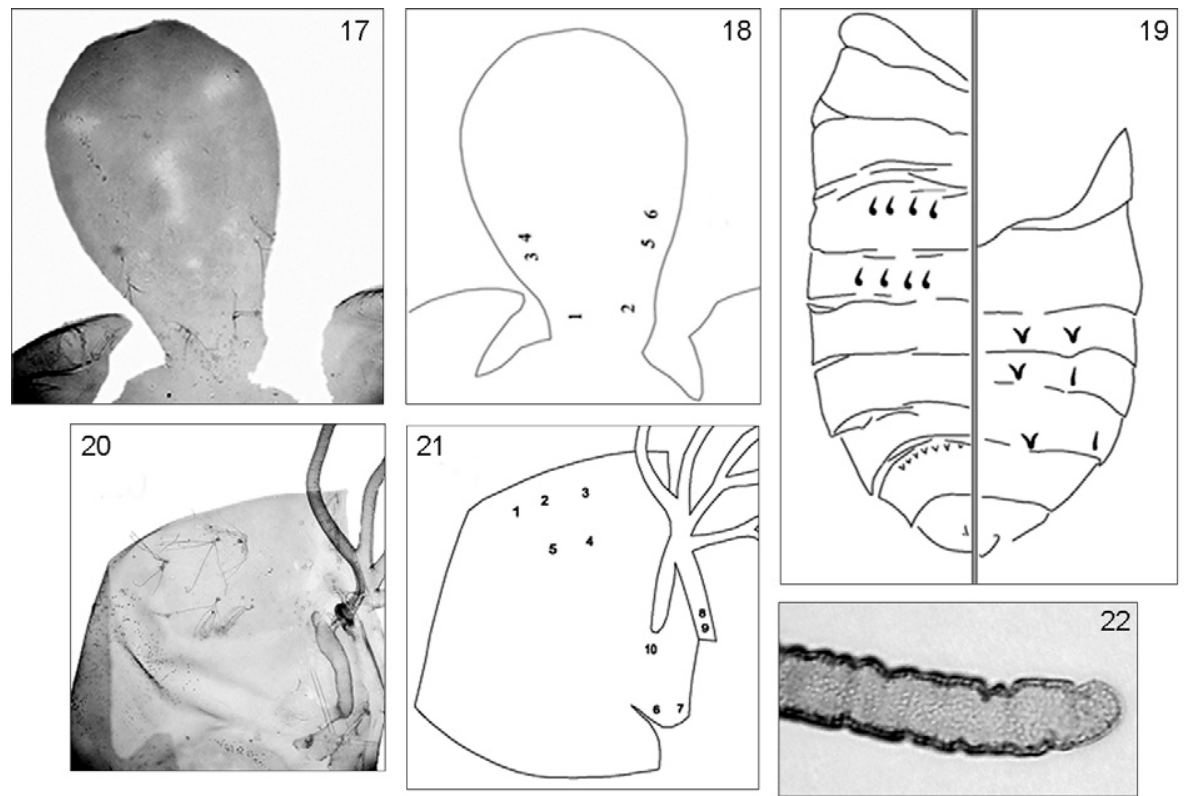

Figs 17-22: Simulium brunnescens sp. nov. (Diptera: Simuliidae) pupa; 17: photograph of head showing pigmentation pattern; 18: schematic drawing of head showing main trichomes position; 19: schematic drawing of abdomen showing main trichomes position (left: dorsal view; right: ventral view); 20: photograph of thorax; 21: schematic drawing of thorax showing main trichomes position; 22: tip of pupa gill. 
equal to the $1+1$ lateral teeth; with $3+3$ sublateral teeth and $2+2$ reduced paralateral teeth; lateral margin of hypostoma with about four serrations per side; hypostoma with $5+5$ setae. Postgenal cleft deep, longer than wide and rounded at the apex (Fig. 26); hypostoma longer than postgenal bridge. Thorax and abdomen: abdomen straight, with pointed distal apex, without ventral tubercles; anal sclerite $\mathrm{x}$-shaped, ventral arm distinctly longer and thinner than the dorsal one; anal ring with about 75 rows of 12 hooks each; rectal organ not observed.

Type data and depository - (CSIOC/Fiocruz) Central South MT Mesoregion, municipality of Rosário do Oeste, unnamed stream on the road from Fazenda São Lucas to Vista Alegre. $15^{\circ} 02^{\prime} 31.2^{\prime \prime S} 56^{\circ} 22^{\prime} 16.3 \mathrm{~W}$ "; altitude $225 \mathrm{~m}$; 1 우 in alcohol with exuvia (holotype) and $10^{\wedge}$ in alcohol with exuvia + 1 pupa in alcohol (paratype) (CSIOC\#2748); $1 \hat{\gamma}$ in alcohol with exuvia (paratype) (CSIOC\#2749). Collectors: M Maia-Herzog, APA Luna Dias, MC Alves and VS Vaz, 10.iv.2003. Brazil Central South MT Mesoregion, municipality of Acorizal, unnamed stream, $15^{\circ} 05^{\prime} 12.2^{\prime \prime S} 56^{\circ} 20^{\prime} 41.6^{\prime \prime} \mathrm{W}$; altitude $252 \mathrm{~m}$; 1 우 in alcohol with exuvia (paratype) (LSO/IOC 1588\#1). Collectors: M Maia-Herzog, APA Luna Dias, MC Alves and VS Vaz, 10.iv.2003. Brazil Central South MT Mesoregion, municipality of Acorizal, Engenho River (near Cachoeirinha/Acorizal), $15^{\circ} 4.1^{\prime} 08^{\prime \prime S} 056^{\circ} 26.8^{\prime} 09^{\prime \prime} \mathrm{W}$; altitude 200 m; 60 pinned with exuviae (paratype) (CSIOC\#2768, $2774,2775,2776,2777,2779) ; 10$ pined with two with exuviae (paratype) (CSIOC\#2767); 10 pinned with exuvia +1 pupa in glycerin (paratype) (CSIOC\#2778); 4 옹 pinned with exuviae (paratype) (CSIOC\#2770, 2771, 2772, 2773); 19 pinned with two exuviae +1 pupa in glycerin (paratype) (CSIOC\#2780); 1 exuvia in a pinned glycerin vial (paratype) (CSIOC\#2769); 19 and $10^{-1}$ on slide with exuviae (paratype) (CSIOC\#2781). Collectors: M MaiaHerzog, APA Luna Dias, MC Alves and AMR Amaral, 08.vii.2003. Brazil Central South MT Mesoregion, municipality of Barão de Melgaço, stream formed by an output of water from an inundated area (BR 364), 15 $5^{\circ} 3^{\prime} 10.1^{\prime \prime} \mathrm{S}$ $55^{\circ} 36^{\prime} 03.9^{\prime \prime} \mathrm{W}$; altitude $215 \mathrm{~m}$; $1 \mathrm{O}^{\text {' }}$ in alcohol with exuvia (paratype) (CSIOC\#2754). Collectors: M Maia-Herzog, APA Luna Dias, MC Alves and VS Vaz, 11.iv.2003. Brazil Central South MT Mesoregion, municipality of Barão

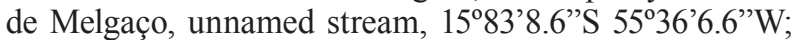
altitude $210 \mathrm{~m} ; 1 \delta^{\lambda}$ in alcohol with exuvia (paratype) (CSIOC\#2755). Collectors: M Maia-Herzog, APA Luna Dias, MC Alves and VS Vaz, 11.iv.2003. Brazil Central South MT Mesoregion municipality of Chapada dos Gui-

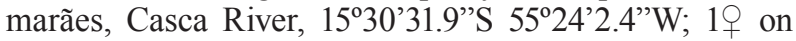
slide with exuvia (LSO/IOC\#2670) and 19 on slide with exuvia (CSIOC\#2671). Collectors: M Maia-Herzog, APA Luna Dias, MC Alves and LH Gil-Azevedo, 23.ii.2003. Brazil Central South MT Mesoregion, municipality of Jangada, Passa Três River, 1514'29.4"S 56 29'36.3”W; altitude $202 \mathrm{~m} ; 2 \widehat{O}^{\wedge}$ in alcohol with exuviae (CSIOC\#2695, 2696); 89 pinned with exuviae (CSIOC\#2697, 2698, 2701, $2702,2704,2716,2722,2723) ; 2$ pinned with exuviae + 1 pupa in glycerin (CSIOC\#2699, 2700); 29 pinned with exuviae +2 pupa in glycerin (CSIOC\#2719), 2 ㅇ pinned with exuviae +1 pupa (CSIOC\#2721); 1 우 and $2 \hat{0}$ pinned on same pin with exuviae (CSIOC \#2715); $19+1{ }^{\lambda}$ pinned with exuviae (LSO/IOC\#2718); 11 र pinned with exuviae (CSIOC\#2705, 2706, 2707, 2708, 2709, 2710, 2711, 2713, $2714,2717,2720) ; 20$ pinned with exuviae +2 pupae in glycerin (CSIOC\#2703), $2 \widehat{\text { }}$ pinned on same pin with exuviae (CSIOC\#2712). Collectors: M Maia-Herzog, APA Luna Dias, MC Alves and VS Vaz, 08.iv.2003. Brazil North MT Mesoregion, municipality of Nobres, Cancela

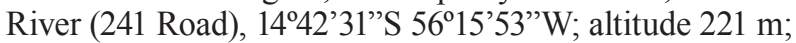
$4 \hat{0}$ pinned with exuviae (paratype) (CSIOC/IOC\#2728, 2729, 2730, 2731). Collectors: M Maia-Herzog, APA Luna Dias, MC Alves and VS Vaz, 08.iv.2003. Brazil North MT Mesoregion, municipality of Paranatinga, MT-020 Road, from Paranatinga to Gaúcha do Norte, Água Imendada River, $14^{\circ} 25^{\prime} 16^{\prime \prime} \mathrm{S} 53^{\circ} 56^{\prime} 00^{\prime \prime} \mathrm{W}$; altitude $507 \mathrm{~m}, 7$ 우 in alcohol with exuviae (CSIOC/IOC\#2672, 2673, 2676, 2680, 2682, 2686 and 2688), 1 ㅇ in alcohol with exuvia +4 pupae
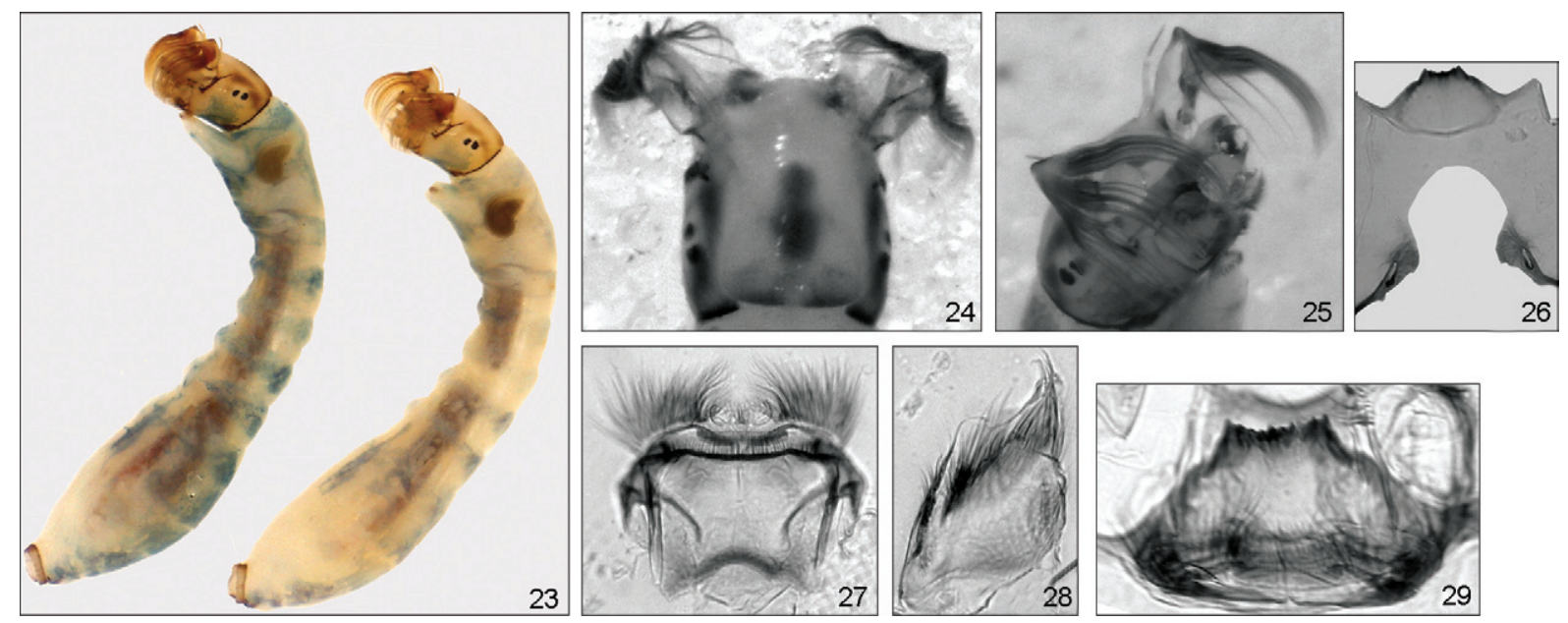

Figs 23-29: Simulium brunnescens sp. nov. larvae; 23: colour pattern of the body, green variation on the left; 24: colour pattern of head capsule; 25: detail of the mouthparts; 26 : postgenal cleft; 27 : maxilla; 28 : mandible; 29: hypostoma. 
(CSIOC/IOC\#2681); 60 in alcohol with exuviae (CSIOC/ IOC\#2674, 2675, 2678, 2683, 2684, 2687), 1 우 with exuvia and $2 \hat{0}$ with exuviae (CSIOC/IOC\#2677, 2679), 1 우 and $10^{-}$in alcohol with exuviae (CSIOC/IOC\#2685); 3 우 and $2 \hat{\gamma}$ on slide with exuviae. Adults are mounted individually and their exuviae are mounted on separate slides (CSIOC/IOC\#2689); 4 우 pinned with exuviae (2 pinned together on the same pin - CSIOC/IOC\#2690 - the rest pinned individually - CSIOC/IOC\#2691, 2694); 1 우 and $10^{\lambda}$ pinned together with exuviae (CSIOC/IOC\#2693). Collectors: M Maia-Herzog, APA Luna Dias, MC Alves and LHG Azevedo, 24.ii.2003. Brazil Central South MT Mesoregion, municipality of Rosário do Oeste, Pai Caetano

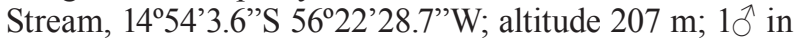
alcohol with exuvia (paratype) (CSIOC/IOC\#2745) and 1 우 pinned with exuvia (paratype) (CSIOC/IOC\#2746). Collectors: M Maia-Herzog, APA Luna Dias, MC Alves and VS Vaz, 10.iv.2003. Brazil Central South MT Mesoregion, municipality of Rosário do Oeste, running water formed by a swamp, $14^{\circ} 55^{\prime} 56.4^{\prime \prime} \mathrm{S} 56^{\circ} 21^{\prime} 51.4$ "'W; altitude $209 \mathrm{~m}$; 1 i in alcohol with exuvia (paratype) (CSIOC/IOC\#2747). Collectors: M Maia-Herzog, APA Luna Dias, MC Alves and VS Vaz, 10.iv.2003. Brazil Central South MT Mesoregion municipality of Rosário, Custodia River (MT-364), $14^{\circ} 54^{\prime} 39^{\prime \prime} \mathrm{S} 56^{\circ} 28^{\prime} 12^{\prime \prime} \mathrm{W}$; altitude $217 \mathrm{~m}$; $10^{\lambda}$ pinned with exuvia (CSIOC/IOC\#2724). Collectors: M Maia Herzog, APA Luna Dias, MC Alves and VS Vaz, 08.iv.2003. Brazil Central South MT Mesoregion, municipality of Chapada dos Guimarães, Mutuca Stream, $15^{\circ} 21^{\prime} 54.5^{\prime \prime} \mathrm{S}$ $55^{\circ} 57^{\prime} 21.2$ 'W; altitude $179 \mathrm{~m}$; five larvae (2 in slide and 3 in alcohol) (LSO/IOC\#ANE01-5). Collectors: ACS Valente, LH Gil-Azevedo and JBC Santos, 31.iii.2010.

Other material examined - S. subpallidum: Brazil, state of Minas Gerais, B. Constant, $16.10[=1910]$; 1 우 pinned [CSIOC\#12.653(lectotype)] (without collector's name but probably collected by A. Lutz.). Brazil, MT, municipality of Chapada dos Guimarães, Rio Claro

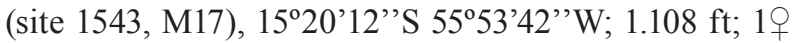
(reared). Collectors: AJ Shelley and M Maia-Herzog, 21.x.2002 (IOC). Brazil Central South, MT Mesoregion, Municipality of Acorizal, Engenho River (near Cachoeirinha/Acorizal), $15^{\circ} 16^{\prime} 08^{\prime \prime} \mathrm{S} 56^{\circ} 26^{\prime} 09^{\prime \prime} \mathrm{W}$; altitude $200 \mathrm{~m}$. 5 ㅇ with exuviae, $3{ }^{\lambda}$ with exuviae and four pupae. Collectors: M Maia-Herzog, APA Luna Dias, MC Alves and AMR Amaral, 08.vii.2003 (BMNH). Brazil North, MT Mesoregion, municipality of Paranatinga, MT-020 Road, from Paranatinga to Gaúcha do Norte, Água Imendada River, $14^{\circ} 25^{\prime} 16^{\prime}$ 'S $53^{\circ} 56^{\prime} 00^{\prime \prime} \mathrm{W}$; altitude $507 \mathrm{~m}, 13$ ? with exuviae and $21 \delta^{\circ}$ with exuviae. Collectors: M Maia-Herzog, APA Luna Dias, MC Alves and LHG Azevedo, 24.ii.2003.

Distribution - We have found S. brunnescens sp. nov. in 13 of all sites surveyed (municipalities of Chapada dos Guimarães, Paranatinga, Rosário do Oeste e Nobres) (Supplementary data). Immatures develop in fast flowing streams 4-10 m wide, with riverbeds that may be rocky, muddy or sandy with clay or silt. $S$. brunnescens sp. nov. was found with S. subpallidum, S. spinibranchium Lutz, 1910, Simulium jujuyense Paterson \& Shannon, Simulium minusculum Lutz, Simulium oyapockense Floch and Abonnenc, Simulium incrustatum Lutz, Simulium perflavum Roubaud, Simulium nigrimanum Macquart and Simulium (Inaequalium) sp.

Etymology - The species name is from the Latin noun meaning "brown", in reference to the browning colour of the adult thorax.

\section{DISCUSSION}

The adults of $S$. brunnescens sp. nov. are similar to the adults of S. subpallidum, but both species can be easily distinguished at the pupal stage. The pupa of S. brunnescens sp. nov. has six gill filaments whereas the pupa of $S$. subpallidum has eight. S. brunnescens $\mathrm{sp}$. nov. has most
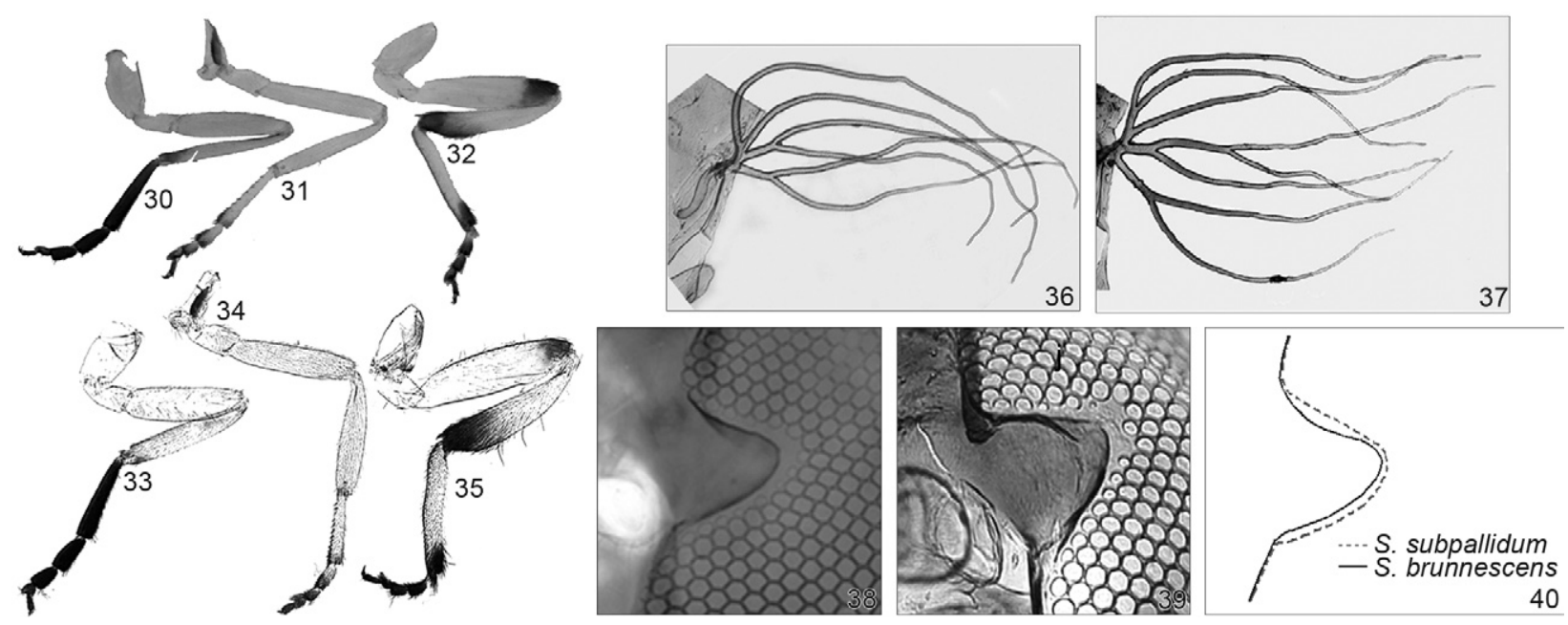

Figs 30-40: comparison between Simulium brunnescens sp. nov. and Simulium subpallidum (Diptera: Simuliidae); 30-32: colour pattern of S. brunnescens sp. nov. legs; 33-35: colour pattern of S. subpallidum legs (after Hernandez et al. 2008); 36: S. brunnescens pupa gill; 37: S. subpallidum's pupa gill (after Hernandez et al. 2008); 38: S. brunnescens' frontal dilatation; 39: S. subpallidum's frontal dilatation (after Hernandez et al. 2008); 40: frontal dilatation of both species, overlaid. 
of the characters that define Simulium (Chirostilbia), especially in the subpallidum-species-group: medium sized species, adults grayish brown to yellowish brown, gonostylus subtriangular and longer than wide at base, ventral plate wider than long, pupal cephalic plate and thorax with scarce or absent tubercles, cocoon slipper-shaped, larval cephalic apotome without basally darker subtriangular area (Coscarón 1991, Coscarón \& Coscarón-Arias 2007, Hernández et al. 2008). For further details characteristics of the subgenus and its species can be found in Hernández et al. (2008) and in Shelley et al. (2010).

Hernandez et al. $(2007,2008)$ examined three specimens of simuliids from the state of Roraima, Brazil, which they considered as variation of $S$. subpallidum, despite the presence of six filaments in the pupal gill, characteristic of $S$. brunnescens sp. nov. Since we did not examine these specimens, we cannot confirm their identity as $S$. brunnescens. However, we agree with Hernandez et al. (2008) that S. subpallidum may correspond to a species-complex.

The Simuliidae are a morphologically homogenous group with many recognized species complexes. Some species can only be identified using the configuration of the pupal gill filaments. The subgenus Inaequalium, for example, is known for the extreme similarity among the adults and apparently trivial differences, such as gill bifurcations or the shape of the apex of the gill are used for species identification. We agree with the literature (WHO 1978, Rothfels 1979, Crosskey 1993, Adler \& Kachvorian 2001) that cytogenetics and molecular biology are promising methods to solve pending taxonomic problems in this family. Nonetheless, the differences between S. brunnescens and S. subpallidum are solid and constant in the examined populations to be considered a new species. Some articles suggest that the ramification pattern of the pupal gill filaments may not be a reliable source of differentiation in some groups due to its high variability. However, recent descriptions of new species based on both classic taxonomy and molecular tools, prove that morphological characteristics once considered to be variations (presence of small tubercles, differences in ramification), are indeed characters of differentiation, e.g. Hamada et al. (2010) recent description of S. litobranchium vs. Simulium guianense.

Besides the number of pupal gill filaments, some other differences could be found between S. brunnescens and $S$. subpallidum in the adults - different colour pattern of the legs (the dark spots on the hindfemur and foretibia of $S$. brunnescens are more conspicuous than the corresponding dots of S. subpallidum), males - the gonostyle is very similar in both species, but it is more slender and pointed in S. brunnescens, ventral plate less rounded than S. subpallidum's, females - the frontal dilatation is broader in $S$. subpallidum than in S. brunnescens (Figs 30-40), larvae - in $S$. brunnescens the coloration is vivid green, while in $S$. subpallidum is greenish gray size about $4 \mathrm{~mm}$ and the postgenal cleft rounded; contrasting if $S$. subpallidum that the coloration is greenish gray, size about $5 \mathrm{~mm}$ and postgular cleft rounded with anterior region narrower. Also, the number of gill filaments on the larval histoblast is different in both species, six in S. brunnescens and eight in S. subpallidum.

\section{ACKNOWLEDGEMENTS}

To Luis Hernández (BMNH), for Figs 1, 2, 4, 11, 12, 14, 15 and 16, to Rodrigo Mexas (Setor de Tratamento de Imagens, IOC/Fiocruz), for Fig. 5, to Clarisse Faria, for helping with the description of the climate and map, to Programa de Pós Graduação em Biodiversidade e Saúde/IOC-Fiocruz, for the support, and to the Parque Nacional Chapada dos Guimarães/IBAMA/ MMA, for the collection license.

\section{REFERENCES}

Adler PH, Crosskey RW 2011. World blackflies (Diptera: Simuliidae): a comprehensive revision of the taxonomic and geographical inventory [monograph on the internet]. South Carolina, Clemson University. [cited 2011 November 18]. Available from: clemson. edu/cafls/departments/esps/biomia/pdfs/blackflyinventory.pdf.

Adler PH, Kachvorian EA 2001. Cytogenetics of the Holarctic black fly Simulium noelleri (Diptera: Simuliidae). Can J Zool 79: 1972-1979.

Calvão-Brito RHS, Maia-Herzog M 2003. Modificação na técnica para montagem de simulídeos (Insecta: Diptera) em lâmina/ lamínula. Rev Bras Zool 20: 773-774.

Coscarón S 1991. Insecta (Diptera: Simuliidae). Fauna de água dulce de la República Argentina, Fundación para la Educación, la ciencia y la Cultura, Buenos Aires, 304 pp.

Coscarón S, Coscarón-Arias CL 2007. Neotropical Simuliidae (Diptera: Insecta). Aquatic biodiversity in Latin America, Vol. 3, Pensoft Publishers, Sofia, 685 pp.

Crosskey RW 1993. Blackflies (Simuliidae). In RP Lane, RW Crosskey, Medical insects and arachnids, Chapman \& Hall, London, p. 241-287.

Hamada N, Pepinelli M, Mattos AA, Luz SLB 2010. A new black fly species from Brazil, closely related to Simulium guianense Wise (Diptera: Simuliidae) revealed by morphological and DNA barcoding. Zootaxa 2428: 22-36.

Hernández LM, Shelley AJ, Luna-Dias APA, Maia-Herzog M 2007. New specific synonymies and taxonomic notes on Neotropical black flies (Diptera: Simuliidae) belonging to the subgenera Chirostilbia Enderlein, Hemicnetha Enderlein, Inaequalium Coscarón \& Wygodzinsky, Psaroniocompsa Enderlein and Psilopelmia Enderlein. Zootaxa 1506: 1-80.

Hernandez LM, Shelley AJ, Luna-Dias APA, Maia-Herzog M 2008. Review of the Neotropical blackfly subgenus Chirostilbia Enderlein (Diptera: Simuliidae) based on adults and pupal morphology. Zootaxa 1834: 1-100.

Myers N, Mittermeier RA, Mittermeier CG, Fonseca GAB, Kent J 2000. Biodiversity hotspots for conservation priorities. Nature 403: 853-858.

Ross JLS 2003. Geografia do Brasil, Editora da Universidade de São Paulo, São Paulo, 548 pp.

Rothfels KH 1979. Cytotaxonomy of blackflies (Simuliidae). Annu Rev Entomol 24: 507-539.

Shelley AJ, Hernandez LM, Maia-Herzog M, Luna Dias APA, Garritano PR 2010. The blackflies (Diptera: Simuliidae) of Brazil. Aquatic biodiversity in Latin America, Vol. 6, Pensoft Publishers, Sofia, 812 pp.

Shelley, AJ, Maia-Herzog M, Lowry CA, Luna-Dias APA, Garritano PR, Shelley A, Camargo M, Carter HG 2000. The Simuliidae (Diptera) of the secondary onchocerciasis focus at Minacu in central Brazil. Bull Nat Hist Mus Lond (Ent) 69: 171-221.

WHO - World Health Organization 1978. Species complexes in the Simuliidae. Bull World Health Organ 56: 53-61. 


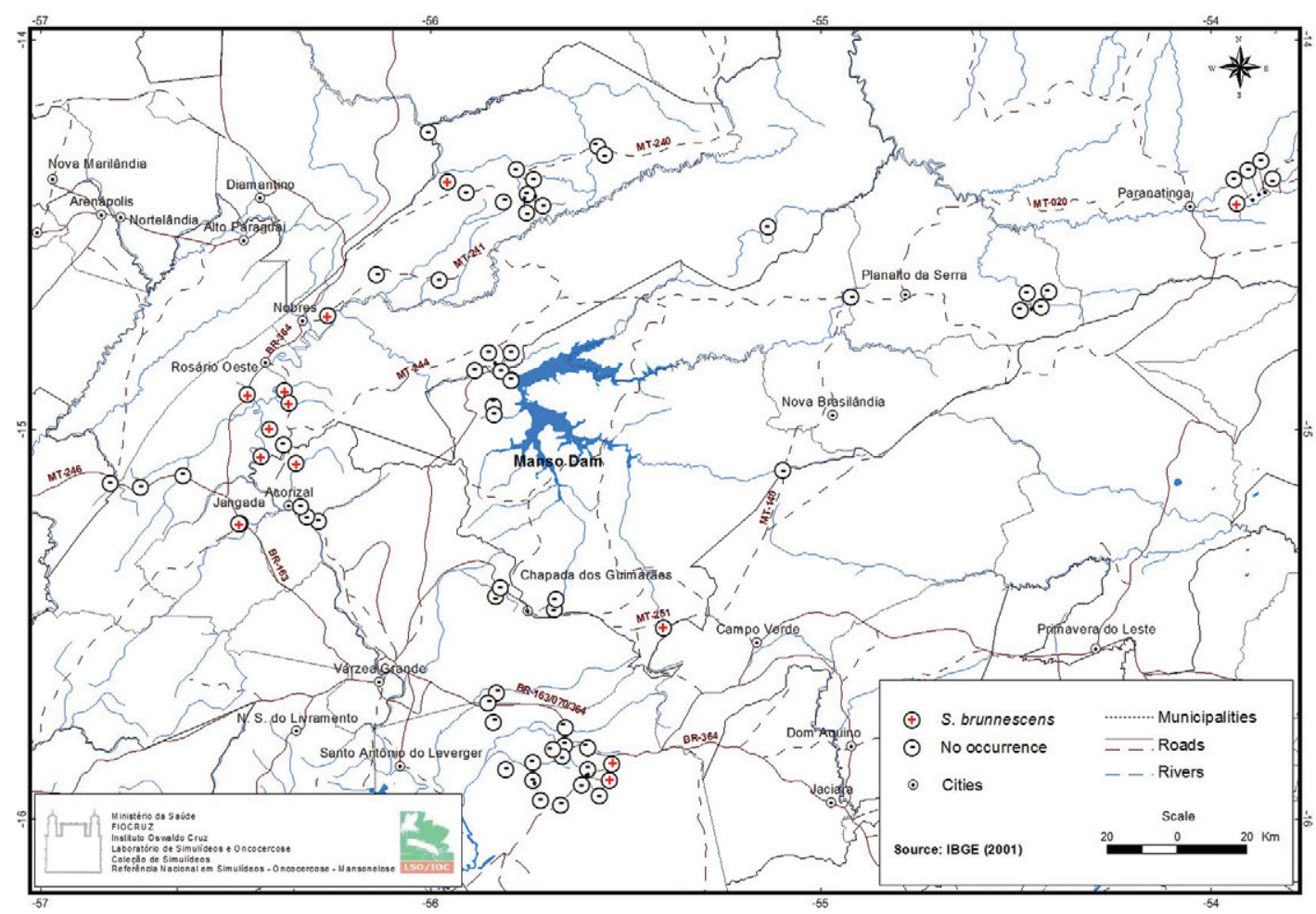

Map of the studied area. Red dots stands for positive locations for Simulium brunnescens sp. nov. (Diptera: Simuliidae). 